\title{
Investigation of Factors Affecting Postoperative Hemoglobin Decrease in Primary Cesarean Sections
}

\author{
(D) Berna Aslan Çetin, (D) Pınar Kadiroğulları, (D) Pınar Yalçın Bahat, (D) Nadiye Köroğlu, (D) Aysu Akça
}

University of Health Sciences, İstanbul Kanuni Sultan Süleyman Training and Research Hospital, Department of Obstetrics and Gynecology, istanbul, Turkey

\section{Abstract}

Objective: The aim of our study was to evaluate the factors affecting postoperative hemoglobin ( $\mathrm{Hb})$ decrease in primary cesarean section patients. Methods: A total of 560 patients who underwent primary caesarean section between January 2016 and December 2016 were evaluated retrospectively. These patients were divided into two groups according to postoperative $\mathrm{Hb}$ values: patients with $\mathrm{Hb}$ decrease $\geq 2 \mathrm{~g} / \mathrm{dL}$ or $<2 \mathrm{~g} / \mathrm{dL}$. There were 142 patients with $\mathrm{Hb}$ decrease $\geq 2 \mathrm{~g} / \mathrm{dL}$. Preoperative and postoperative $24^{\text {th }}$ hour $\mathrm{Hb}$ and hematocrit levels, and factors leading to $\mathrm{Hb}$ decrease were evaluated.

Results: Of the 560 pregnant women included in the study, 289 (51.60\%) had emergent caesarean sections, while 271 (48.39\%) were elective cesarean sections. Demographic data, distribution of cesarean indications and obstetric characteristics were not different between the two groups. Postoperative erythrocyte transfusion requirement was significantly different between the groups $(p<0.001)$. The development of atony and additional uterotonic requirement were significantly higher in the group with $\mathrm{Hb}$ decrease $\geq 2 \mathrm{~g} / \mathrm{dL}$.

Conclusion: Postoperative $\mathrm{Hb}$ decrease is relatively rare in primary cesarean sections. Although severe blood loss and blood product transfusion are rare, caution should be exercised if there is a risk factor in primary cesarean sections.

Keywords: Cesarean delivery, hematocrit decrease, hemoglobin decrease

\section{INTRODUCTION}

According to World Health Organization (WHO) data, it is estimated that around $30 \%$ of the population and more than half of the pregnant women are anemic worldwide. The prevalence of anemia during pregnancy is reported to be $35-50 \%$ (1). Anemia is also an important health problem in our country (2). Hemoglobin $(\mathrm{Hb})$ level below $11.0 \mathrm{~g} / \mathrm{dL}$ in the first and third trimesters, and below $10.5 \mathrm{~g} / \mathrm{dL}$ in the second trimester in pregnant women is defined as anemia $(3,4)$.

There are different claims about the maternal and perinatal effects of anemia during pregnancy. WHO suggests that anemia may contribute to $20 \%$ of maternal deaths $(1,5)$. In addition, maternal anemia has been found to be associated with fetal complications such as intrauterine growth retardation, preterm delivery, low birth weight and maternal complications such as preeclampsia and eclampsia (6-10). Therefore, anemia is an important health problem in terms of female and maternal health. The most common cause of maternal mortality is postpartum hemorrhage and postpartum hemorrhage is the most important cause of morbidity with a rate of $18 \%$ in developed and developing countries (5).

Bleeding is one of the most common complications during and after cesarean section and may be a life-threatening event. The need for a blood transfusion for cesarean section is $2.2 \%$ in recurrent cesarean and $3.2 \%$ in primary cesarean section $(10,11)$.

E-posta: bernaaslan14@hotmail.com ORCID ID: orcid.org/0000-0001-6856-1822 
The aim of our study was to determine the factors affecting the postoperative $\mathrm{Hb}$ decrease in primary cesarean section patients.

\section{METHODS}

There were 12.548 births in our hospital between January 2016 and December 2016. Primary cesarean section cases accounted for $1.914(15.25 \%)$ of these deliveries. Pregnant women were standardized as between 18 and 40 years of age, use of iron and/or multivitamin preparation during pregnancy, and cesarean for the first time. Patients with any placental insertion anomaly, caesarean section due to placental detachment, previous cesarean section, maternal connective tissue diseases and pregnancies below 37 weeks were not included in the study. Five hundred and sixty patients who met the criteria and who had complete medical data were retrospectively reviewed. One hundred and forty-two patients with $\mathrm{Hb}$ decrease more than $2 \mathrm{~g} /$ $\mathrm{dL}$ were detected.

According to our hospital protocol, all patients received 10 units of oxytocin in $0.9 \%$ sodium chloride $1000 \mathrm{~mL}$ following the delivery of the placenta during a caesarean section. Complete blood count was performed 24 hours after surgery. To identify factors associated with severe $\mathrm{Hb}$ decrease $(\geq 2 \mathrm{~g} / \mathrm{dL}$ ), data were obtained from our hospital database records. Demographic and obstetric data such as maternal age, gestational week at delivery, cesarean section indication, maternal additional systemic disease, body mass index (BMI), neonatal birth weight, duration of operation and pregnancy complications were recorded.

\section{Statistical Analysis}

Statistical analysis was performed using SPSS ver. 16.0 package program (Chicago, IL, USA). In addition to descriptive statistical methods (mean, standard deviation), independent t-test was used for comparison of groups and chi-square test was used for the comparison of qualitative data. Logistic regression analysis was performed to determine the factors affecting $\mathrm{Hb}$ decrease. The results were evaluated at $p<0.05$ level.

\section{RESULTS}

Of the 560 pregnant women included in the study, 289 (51.60\%) had cesarean section for emergency reasons and 271 (48.39\%) had elective cesarean section. The distribution of cesarean indications of the two groups is shown in Table 1. While cephalopelvic disproportion was the most common indication in the group with $\mathrm{Hb}$ decrease, it was obstructed labor in the group without $\mathrm{Hb}$ decrease.
The mean age was found to be $27.90 \pm 5.91$ in the group with $\mathrm{Hb}$ decrease less than $2 \mathrm{~g} / \mathrm{dL}$, and $28.85 \pm 6.40$ in the group with $\mathrm{Hb}$ decrease more than $2 \mathrm{~g} / \mathrm{dL}$. Maternal BMI and diseases (diabetes, hypertension, thyroid dysfunction) were similar in both groups. The mean gestational week was $38.41 \pm 2.18$ in the group with $\mathrm{Hb}$ decrease less than $2 \mathrm{~g} / \mathrm{dL}$ and $38.81 \pm 1.89$ in the other group (Table 2).

Uterotonic was used during labor in 153 patients in the group with $\mathrm{Hb}$ decrease less than $2 \mathrm{~g} / \mathrm{dL}$ and in 75 patients in the group with $\mathrm{Hb}$ decrease more than $2 \mathrm{~g} / \mathrm{dL}$. Complications such as bladder injury, vascular injury, t incision dehiscence, intraoperative and/ or postoperative atony and additional uterotonic use were seen in 104 patients (25\%) in the group with $\mathrm{Hb}$ decrease less than 2 $\mathrm{g} / \mathrm{dL}$ and in $76(49.9 \%)$ patients in the group with $\mathrm{Hb}$ decrease more than $2 \mathrm{~g} / \mathrm{dL}$. Atony and additional uterotonic requirement were significantly higher in the group with more $\mathrm{Hb}$ decrease.

Postoperative erythrocyte suspension transfusion was performed in one (0.2\%) patient with $\mathrm{Hb}$ decrease less than $2 \mathrm{~g} / \mathrm{dL}$ and in 11 (7.7\%) patients with $\mathrm{Hb}$ decrease more than $2 \mathrm{~g} / \mathrm{dL}$ (Table 2). Postoperative erythrocyte transfusion requirement was significantly different between the groups $(p<0.001)$.

The risk factors detected in patients with postoperative $\mathrm{Hb}$ decrease more than $2 \mathrm{~g} / \mathrm{dL}$ are shown in Table 3. An infantile head circumference greater than $37 \mathrm{~cm}$ was the most important risk factor, followed by maternal additional disease, macrosomic infant, multiple pregnancy, and uterotonic use during labor, respectively.

\section{DISCUSSION}

Cesarean section is the most common major obstetric operation. Bleeding is the most common complication during and after cesarean section. According to WHO, iron-deficiency anemia rate

\begin{tabular}{|l|l|l|l|}
\hline \multicolumn{4}{|l|}{ Table 1. The distribution of caesarean indications } \\
\hline & $\begin{array}{l}\text { Hgb } \\
\text { decrease }<2 \\
\text { g/dL (n=418) }\end{array}$ & $\begin{array}{l}\text { Hgb decrease } \\
\mathbf{2} \text { g/dL } \\
(\mathbf{n}=142)\end{array}$ & $\mathbf{p}$ \\
\hline Fetal distress & $86(20.57 \%)$ & $30(\% 21.12)$ & 0.54 \\
\hline Obstructed labor & $102(26.79 \%)$ & $29(\% 20.42)$ & 0.38 \\
\hline Cephalopelvic disproportion & $108(24.40 \%)$ & $35(\% 24.64)$ & 0.87 \\
\hline Multiple pregnancy & $20(4.78 \%)$ & $10(\% 7.04)$ & 0.35 \\
\hline Failed induction & $25(5.98 \%)$ & $2(\% 1.40)$ & 0.17 \\
\hline Breech presentation & $73(17.46 \%)$ & $26(\% 18.30)$ & 0.78 \\
\hline LGA infant & $9(2.15 \%)$ & $7(\% 4.92)$ & 0.22 \\
\hline Severe preeclampsia & $5(1.19 \%)$ & $3(\% 2.11)$ & 0.64 \\
\hline Hgb: Hemoglobin, LGA: Large for gestational age & \\
\hline
\end{tabular}


is $14 \%$ in Europe and 25\% in Turkey (2). In this study, prepartum and postpartum $\mathrm{Hb}$ and hematocrit ( $\mathrm{Hct}$ ) levels in pregnant women were examined and the factors causing decrease in standardized mean $\mathrm{Hb}$ and $\mathrm{Hct}$ levels were determined.

In our study, we aimed to reveal the factors affecting the postoperative $\mathrm{Hb}$ decrease in patients who underwent primary cesarean section. There are studies accepting a preoperative and postoperative $\mathrm{Hb}$ difference more than $1 \mathrm{~g} / \mathrm{dL}, 2 \mathrm{~g} / \mathrm{dL}$ or $2.5 \mathrm{~g} /$ dL significant (12-14). In our study, we accepted a difference of more than $2 \mathrm{~g} / \mathrm{dL}$ significant.

In the literature, the rate of $\mathrm{Hb}$ decrease after cesarean section is reported as $0.6-1.8 \%$. Although our findings are consistent with the literature, there are not many studies with sufficient data comparing $\mathrm{Hb}$ values before and after cesarean section (15-17).
Consistent with our findings, previous studies have shown that patients requiring an emergent caesarean section have increased blood loss compared to elective cesarean section and require more blood transfusion $(18,19)$. While there is no difference between the groups regarding cesarean indications, conditions with increased atony are also risk factors for postoperative $\mathrm{Hb}$ decrease.

\begin{tabular}{|l|l|}
\hline $\begin{array}{l}\text { Table 3. Determination of risk factors in cases with } \\
\text { hemoglobin decrease }\end{array}$ \\
\hline Risk factors & 0dds ratio (95\% Cl) \\
\hline Uterotonic use during labor & $1.37(0.38-4.93)$ \\
\hline Macrosomic infant & $3.69(0.92-14.86)$ \\
\hline Multiple pregnancy & $3.00(0.61-14.85)$ \\
\hline Head circumference greater than $37 \mathrm{~cm}$ & $5.41(1.49-19.65)$ \\
\hline Maternal additional disease & $3.85(1.09-13.66)$ \\
\hline
\end{tabular}

Table 2. Demographic data and obstetric outcomes of pregnant women

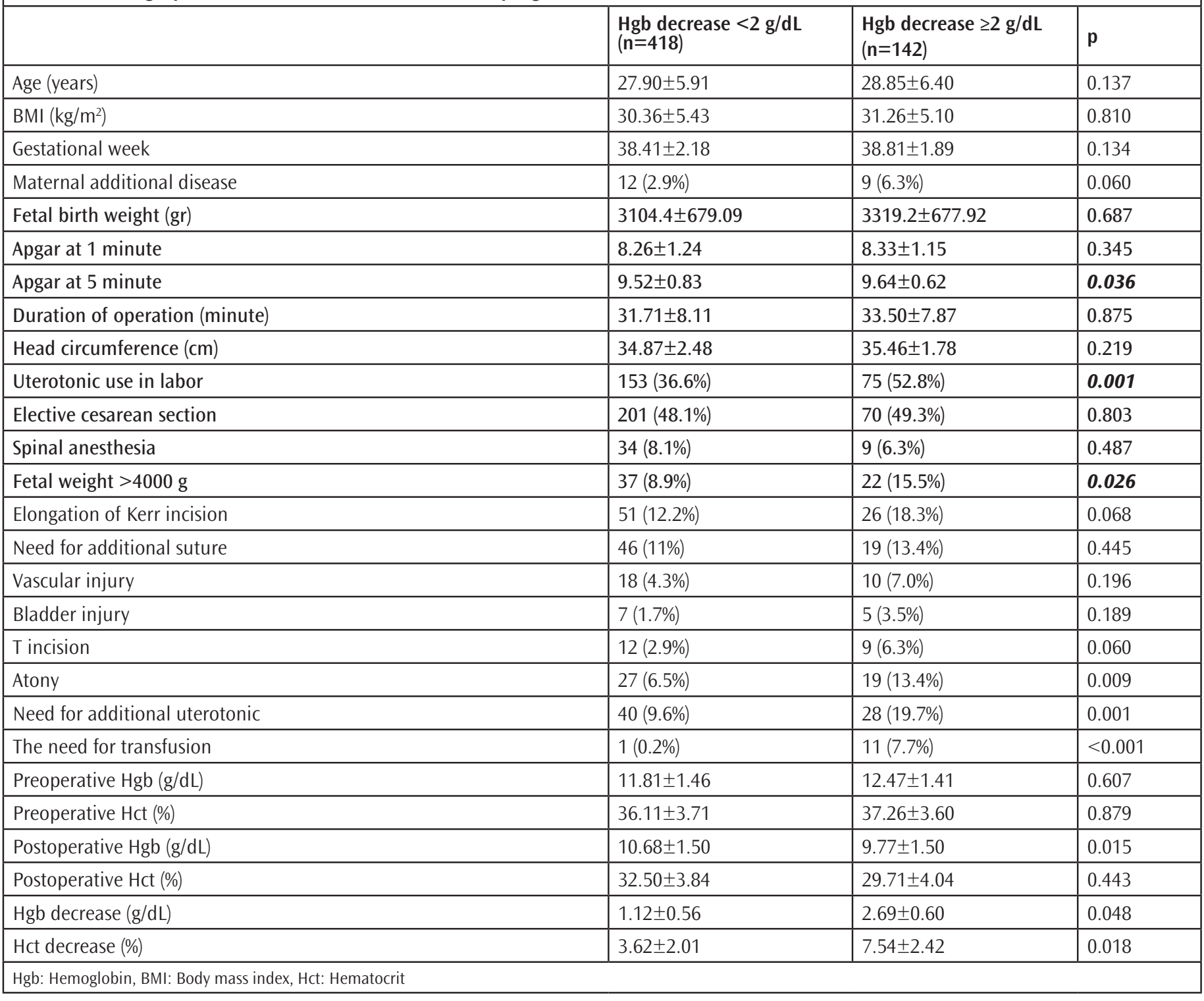


Other risk factors associated with blood loss and the need for transfusion were general anesthesia, factors associated with uterine atony, increased parity, increase in newborn birth weight, prolonged surgical duration, failed labor induction, prolonged labor, and obstructed labor during the second phase (11, 16, 19, 20). In our study, these criteria were also evaluated, and an infantile head circumference greater than $37 \mathrm{~cm}$ was the most important risk factor in patients with $\mathrm{Hb}$ decrease more than $2 \mathrm{~g} /$ $\mathrm{dL}$, followed by maternal additional disease, macrosomic infant (>4000 g), multiple pregnancy and uterotonic use in labor. These factors are also risk factors for development of atony. In our study, atony rate was significantly higher in the group with $\mathrm{Hb}$ decrease more than $2 \mathrm{~g} / \mathrm{dL}$. We found no difference between the two groups in terms of anesthesia type and intraoperative complications. This supports the idea that development of atony is an important factor for postoperative $\mathrm{Hb}$ decrease.

Studies have shown that visual estimates of peripartum blood loss are often incorrect, and other studies have shown that high blood loss is associated with a false estimate (21-24). Blood transfusion rate after cesarean section is $1.1-7.8 \%$ in developed countries and $25 \%$ in developing countries. In our study, the rate of blood transfusion was $2.1 \%$ (12 patients). In 11 of these patients, $\mathrm{Hb}$ decrease was more than $2 \mathrm{~g} / \mathrm{dL}$. The other case was the patient who underwent blood transfusion after emergent cesarean section because of low preoperative $\mathrm{Hb}$ level.

\section{Study Limitations}

The limitations of our study are retrospective design and limited number of patients. Besides, data on additional factors that caused differences in $\mathrm{Hb}$ levels, such as maternal smoking status, were lacking.

\section{CONCLUSION}

In conclusion, postoperative $\mathrm{Hb}$ decrease is relatively rare in primary cesarean sections. Although severe blood loss and blood product transfusion are rare, caution should be exercised if there is a risk factor in primary cesarean sections.

\section{Ethics}

Ethics Committee Approval: Retrospoective study.

Informed Consent: Retrospoective study.

Peer-reviw: Externally peer-reviewed.

\section{Authorship Contributions}

Concept: B.A.C.., Design: N.K., Data Collection or Processing: P.Y.B., Analysis or Interpretation: N.K., A.A., Literature Search: P.K., P.Y.B., Writing: B.A.C., P.K.
Conflict of Interest: No conflict of interest was declared by the authors.

Financial Disclosure: The authors declared that this study received no financial support.

\section{REFERENCES}

1. World Health Organisation. The prevalance of anemia in women: a tabulation of available information. Geneva, Switzerland, WHO-The prevalance of anemia in women: a tabulation of available information. 2nd ed. 1992.

2. Kaya D, Akan $\mathrm{N}$. The incidence of anemia and affecting factors in pregnant women at one neighgborhood primary health care center. Turkiye Klinikleri J Nurs 2010;2:100-9.

3. Worldwide prevalence of anaemia 1993-2005, 2nd edition, Geneva: World Health Organization, 2008, page 5-6.

4. Api O, Bayer F, Akıl A, Bektaș M, Api M, Dabak R, et al. The etiologic and demographic factors related to ane $\neg$ mia prevalence in the pregnant women admitting to an education and research hospital in Istanbul. Perinatoloji Dergisi 2009;17:28-34.

5. Harma M, Harma M, Yurtseven S, Demir N. Frequency of anemia among multiparous pregnant women. Turkiye Klinikleri J Gynecol Obst 2004;14:125 .

6. Huisman A, Aarnoudse JG. Increased 2nd trimester hemoglobin concentration in pregnancies later complicated by hypertension and growth retardation. Early evidence of a reduced plasma volume. Acta Obstet Gynecol Scand 1986;65:605-8.

7. 7.Murphy JF, O'Riordan J, Newcombe RG, Coles EC, Pearson JF. Relation of haemoglobin levels in first and second trimesters to outcome of pregnancy. Lancet 1986;1:992-5.

8. Stephansson O, Dickman PW, Johansson A, Cnattingius S.Maternal hemoglobin concentration during pregnancy and risk of stillbirth. JAMA 2000;284:2611-7.

9. Levy A, Fraser D, Katz M, Mazor M, Sheiner E. Maternal anemia during pregnancy is an independent risk factor for low birthweight and preterm delivery. Eur J Obstet Gynecol Reprod Biol 2005;122:182-6.

10. McMahon MJ, Luther ER, Bowes WA Jr, Olshan AF. Comparison of a trial of labor with an elective second cesarean section. N Engl J Med 1996;335:68995.

11. Rouse DJ, MacPherson C, Landon M, Varner MW, Leveno KJ, Moawad AH, et al. Blood transfusion and cesarean delivery. Obstet Gynecol 2006;108:891-7.

12. Dehgbashi S, Honarvar M, Fardi FH. Manual removal or spontaneous placental delivery and post cesarean endometritis and bleeding. Int J Gynaecol Obstet 2004;86:12-5.

13. Morales M, Ceysens G, Jastrow N, Viardot C, Faron G, Vial Y, et al. Spontaneous delivery or manual removal of the placenta during caesarean section: a randomised controlled trial. BJOG 2004;111:908-12.

14. Shaheen M, Khurshid S, Asghar M. Blood loss in manual extraction of placenta versus spontaneous delivery during elective cesarean section. Gomal Journal of Medical Sciences 2014;12:168-71.

15. Horowitz E, Yogev Y, Ben-Haroush A, Rabinerson D, Feldberg D, Kaplan B. Routine hemoglobin testing following an elective Cesarean section: is it necessary? J Matern Fetal Neonatal Med 2003;14:223-5.

16. Combs CA, Murphy EL, Laros RKJ. Factors associated with hemorrhage in cesarean deliveries. Obstet Gynecol 1991;77:77-82. 
17. Api O, Unal O, Api M, Dogance U, Balcik O, Kara O, et al. Do asymptomatic patients require routine hemoglobin testing following uneventful, unplanned cesarean sections? Arch Gynecol Obstet 2010;281:195-9.

18. Chua SC, Joung SJ, Aziz R. Incidence and risk factors predicting blood transfusion in cesarean section. Aust N Z J Obstet Gynaecol 2009;49:490-3.

19. Skjeldestad FE, Oian P. Blood loss after cesarean delivery: a registry-based study in Norway, 1999-2008. Am J Obstet Gynecol 2012;206:76.e1-7.

20. Rouse DJ, Leindecker S, Landon M, Bloom SL, Varner MW, Moawad AH, et al. The MFMU cesarean registry: uterine atony after primary cesarean delivery. Am J Obstet Gynecol 2005;193:056-60.
21. Prasertcharoensuk W, Swadpanich U, Lumbiganon P. Accuracy of the blood loss estimation in the third stage of labor. Int J Gynecol Obstet 2000;71:6970

22. Wallace G. Blood loss in obstetrics using a haemoglobin dilution technique. J Obstet Gynaecol Br Commonw 1967;74:64-7.

23. Razvi K, Chua S, Arulkumaran S, Ratnam SS. A comparison between visual estimation and laboratory determination of blood loss during the third stage of labour. Aust N Z J Obstet Gynaecol 1996;36:152-4.

24. Stafford I, Dildy GA, Clark SL, Belfort MA. Visually estimated and calculated blood loss in vaginal and cesarean delivery. Am J Obstet Gynecol 2008;199:519.e1-7. 